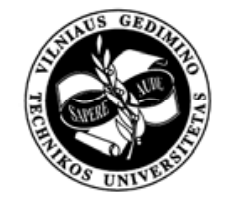

\title{
INVESTIGATION INTO HEAVY METALS IN STORM WASTEWATER FROM VILNIUS ŽIRMŪNAI DISTRICT AND POLLUTANTITS SPREAD MODEL IN NERIS RIVER
}

\author{
Saulius Vasarevičius ${ }^{1}$, Asta Mineikaitė ${ }^{2}$, Petras Vaitiekūnas ${ }^{3}$ \\ Dept of Environmental Protection, Vilnius Gediminas Technical University, \\ Sauletekio al. 11, LT-10223 Vilnius, Lithuania \\ E-mail: ${ }^{1}$ saulius@vgtu.lt; ${ }^{2}$ pretekstas@gmail.com; ${ }^{3}$ vaitiek@itpa.lt \\ Submitted 3 June 2008; accepted
}

\begin{abstract}
The paper discusses investigation into uncleaned storm wastewater pollution with heavy metals in Vilnius Žirmūnai district. The goal is to determine the dependency of storm wastewater pollution with heavy metals on transport intensity. After determining this dependency, sweeps from street points is experimentally studied with the most intensive transport flows. As the street sweeps together with storm wastewater are both outflow from streets and through outflow pipes directly to the Neris, heavy metals in the outflow pipe sludge are also studied for each pool. The following heavy metals have been experimentally studied: $\mathrm{Pb}, \mathrm{Mn}, \mathrm{Cr}, \mathrm{Zn}, \mathrm{Cu}$, Ni. The flame atomic absorption spectrometry method was used. The process of analysis is explained in short and its results are provided. A mathematical model by Phoenics 3.5 version program showing the distribution of heavy metals in the Neris river stream is made on the basis of the results received.
\end{abstract}

Keywords: storm wastewater, outflow pipe, heavy metals, street sweeps, Neris river, Žirmūnai, spread of pollutants.

\section{Introduction}

Urban environment is a complicated system, because 70 $90 \%$ of all the soil lies under the streets, pedestrian paths, buildings and therefore, its natural environmental recovery takes a lot of time, a natural energy and material circulation are destroyed. Street surface could protect soil from pollution like a filter, however natural filtration disappears and in this way, pollutants, heavy metals in this case (zinc, copper, lead, manganese, nickel, chrome) from the streets flow to the waste pipes and directly to the rivers (German et al. 2002]). Zinc (Zn) keeps in soil up to 70-510 years, cadmium (Cd) - 13-1100 years, copper (Cu) - 310-1500 years, lead $(\mathrm{Pb})$ - 749-5900 years (Jankauskaitė 2002; Taraškevičius et al. 1998). Heavy metals cannot ruin or be destroyed, they accumulate in living organisms and have a harmful influence on human beings and living organisms and water biota (Lee et al. 2006; Brannvall et al. 2007).

One of the major pollutants in the city is transportat. Large amounts of transport pollutants go directly on the streets and around the driving part of the road (Jucevičienè 2003; Csereklye 2010). Most of the heavy metals from transport spread through flue gas, oils (during accidents), wearing tires and brakes, deteriorating street surface (Davis et al. 2001; Sorme et al. 2002).

The main goal of the investigation is to determine through experiment, the pollution of uncleaned storm wastewater, outflowing into the Neris river through out- flow pipes, with heavy metals starting from Žirmūnai district and make a model for pollutant spread in the river stream.

\section{Investigation methodology}

For performing a test for heavy metals concentration in storm wastewater outflow, the researchers chose Žirmūnai district in Vilnius city with the biggest number of inhabitants (Fig. 1). For acquiring the relation between storm wastewater outflow and those of heavy metals from the vehicles, the street sweeping samples from the street points having the greatest amount of vehicle flows and sludge samples from the outflow pipes in Žirmūnai district are taken. The samples taken are studied at research lab in the Department of Environmental Protection at VGTU according to methodology: "Measuring the concentration of heavy metals in the sewage, soil, ground and sludge with a flame atomic absorption spectometry“.

Dried samples are sieved through Retsch AS200 sieves up to $1 \mathrm{~mm}$ sieve. Each sample is weighed by $0.500 \mathrm{~g}$ each and reduced with a $12 \mathrm{ml}$ nitric acid $\left(\mathrm{HNO}_{3}\right)$ and hydrochloric acid $(\mathrm{HCl})$ solution with an appropriate proportion 1:3. Ready-made samples are mineralized with Milestone Microwave. After the mineralization process, sample solutions are diluted by $50 \mathrm{ml}$ distilled water and analyzed with flame atomic absorption spectrometer Buck Scientific 210 VGP. 


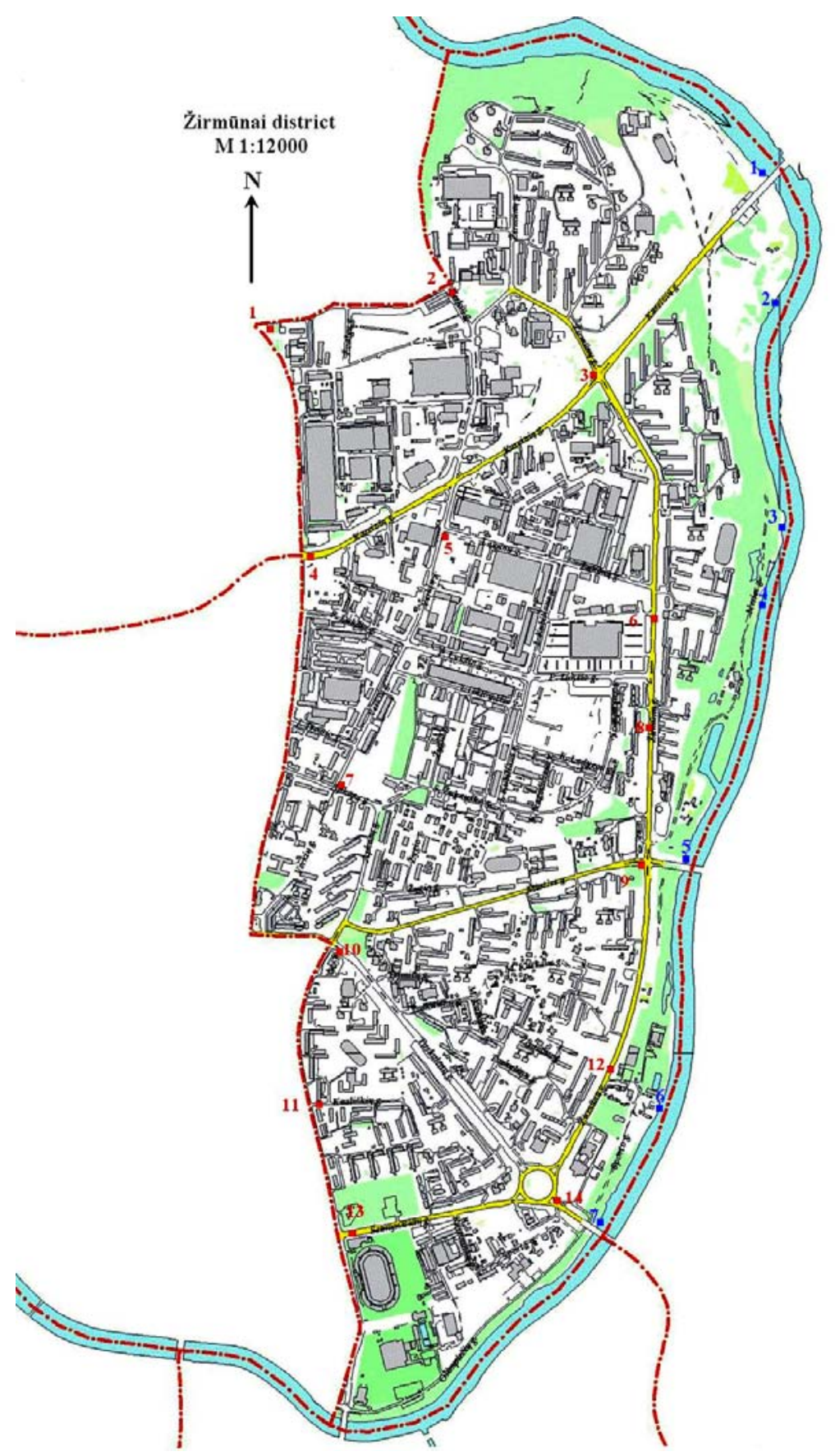

Fig. 1. Sampling points in Žirmūnai district. 1, 2 etc. - the highest intensity transport points (samples of sweeps); 5, 7 etc. - outflow number (samples of storm wastewater)

\section{Investigation results}

Concentration of heavy metals ( $\mathrm{Cr}, \mathrm{Zn}, \mathrm{Mn}, \mathrm{Ni}, \mathrm{Pb}, \mathrm{Cu})$ $(\mathrm{mg} / \mathrm{l})$ in street sweeps (Fig. 2) and in sludge from the storm wastewater outflow pipes (Fig. 3) are measured with a flame atomic absoprtion spectrometer.

The highest concentrations are those of $\mathrm{Mn}, \mathrm{Zn}, \mathrm{Cu}$ (in street sweep) and $\mathrm{Pb}$ (in sludge). According to the hygienic norms (HN 60:2004) heavy metals in street sweeps and sludge exceed the norms 11 times (Table 1).

According to the data analyzed, concentration of heavy metals in street sweeps have no direct dependency on transport intensity. It is clearly indicated in Fig. 4, where the concentration of the major heavy metals $\mathrm{Zn}$ and $\mathrm{Mn}$ in street sweep are presented subject to transport intensity. 


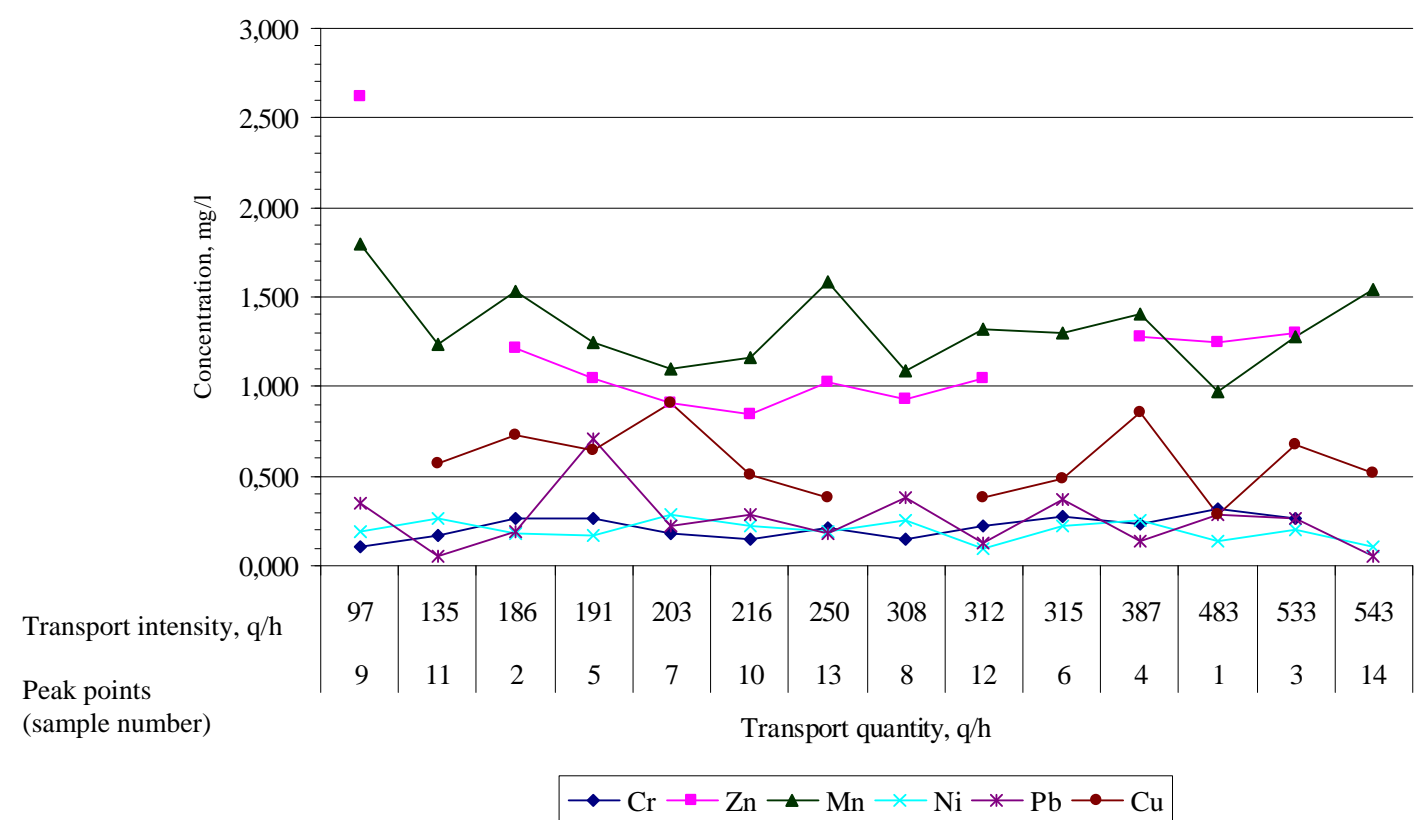

Fig. 2*. Comparison of heavy metals concentration $(\mathrm{mg} / \mathrm{l})$ of sweeps by transport quantity $(\mathrm{q} / \mathrm{h})$ at peak points *Comment. There are gaps in point 6 and 11 of $\mathrm{Zn}$ and in point 8 of $\mathrm{Cu}$, because results are above confidence interval

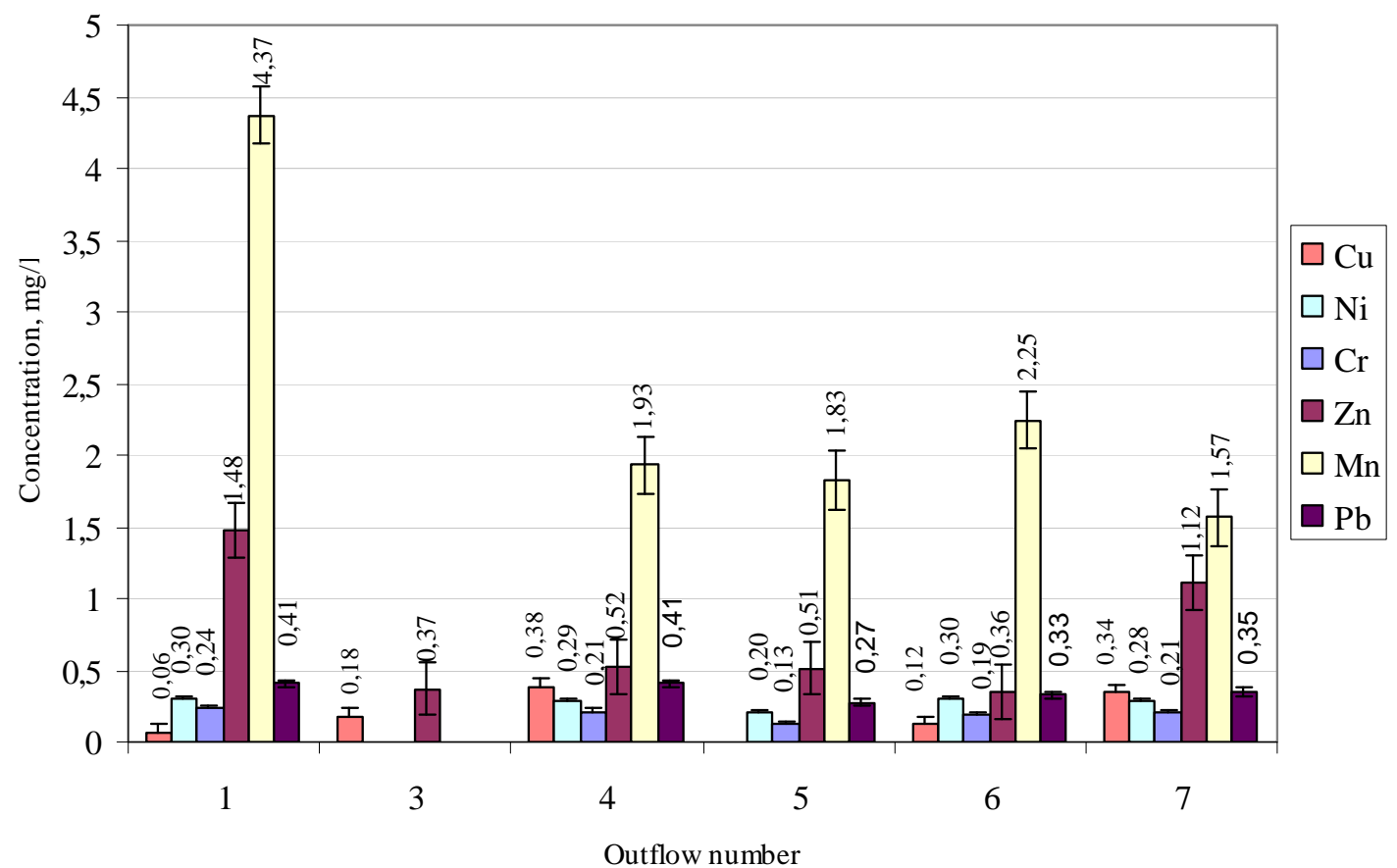

Fig. 3. Heavy metals concentration in outflow *Comment. There are gaps in outflow 3 of $\mathrm{Ni}, \mathrm{Cr}, \mathrm{Mn}, \mathrm{Pb}$ and 5 of $\mathrm{Cu}$, because results are above confidence interval

Consequently, concentration of heavy metals in street sweeps depends on the surrounding environment (green zones, surrounding companies and industry, fuel, vehicle repair shops), frequency and time of vehicle stops because of the traffic jams and crossroads, driving speed, number of accidents, frequency of street sweeps works (sweeps export). Part of heavy metals get to streets from roofs $(\mathrm{Cu}$, $\mathrm{Zn}, \mathrm{Pb}$ ), wearing street surfaces. A general concentration of heavy metals (general pollution) in Žirmūnai geographical territory is presented in Fig. 5. The highest rate of pollution is seen around points 6 and 9 . These points are close to the Neris river valley. Close points are car parking lot, car repair shop, administrative buildings, electricity company - in comparison with other points, the latter streets are rarely swept or almost never swept (point 6), karting field, administrative and residential houses, fuel station (point 9). The higher concentration of heavy metals lies in the northern part of Žirmūnai. The lowest concentrations are at points 11 and 14. Around these points, there are crossroads without traffic light-control, however, there‘s a market, residential houses, many trees (point 11), administrative buildings, fuel station, supermarket and streets are often cleaned (point 14). 
Table 1. Heavy metals excess in samples by MPC

\begin{tabular}{|c|c|c|c|c|c|c|}
\hline \multicolumn{7}{|c|}{ Sweeps from street } \\
\hline \multirow{3}{*}{$\begin{array}{c}\text { MPC } \\
(\mathrm{mg} / \mathrm{kg})\end{array}$} & $\mathrm{Cr}$ & $\mathrm{Zn}$ & $\mathrm{Mn}$ & $\mathrm{Ni}$ & $\mathrm{Pb}$ & $\mathrm{Cu}$ \\
\hline & 100 & 300 & 1500 & 75 & 100 & 100 \\
\hline & \multicolumn{6}{|c|}{ no exceed } \\
\hline \multirow{2}{*}{$\begin{array}{c}\text { Background } \\
\text { MPC } \\
(\mathrm{mg} / \mathrm{kg}) \\
\end{array}$} & 30 & 26 & 427 & 12 & 15 & 8.1 \\
\hline & in 1 point & to $11 \mathrm{x}$ & no exceed & to $3 x$ & to $5 x$ & to $11 \mathrm{x}$ \\
\hline \multicolumn{7}{|c|}{ Sludge from outflows } \\
\hline \multirow{3}{*}{ MPC (mg/l) } & $\mathrm{Cr}$ & $\mathrm{Zn}$ & $\mathrm{Mn}$ & $\mathrm{Ni}$ & $\mathrm{Pb}$ & $\mathrm{Cu}$ \\
\hline & 0.5 & 0.4 & - & 0.2 & 0.1 & 0.5 \\
\hline & no exceed & to $4 \mathrm{x}$ & - & to $1.5 \mathrm{x}$ & to $4 \mathrm{x}$ & no exceed \\
\hline
\end{tabular}

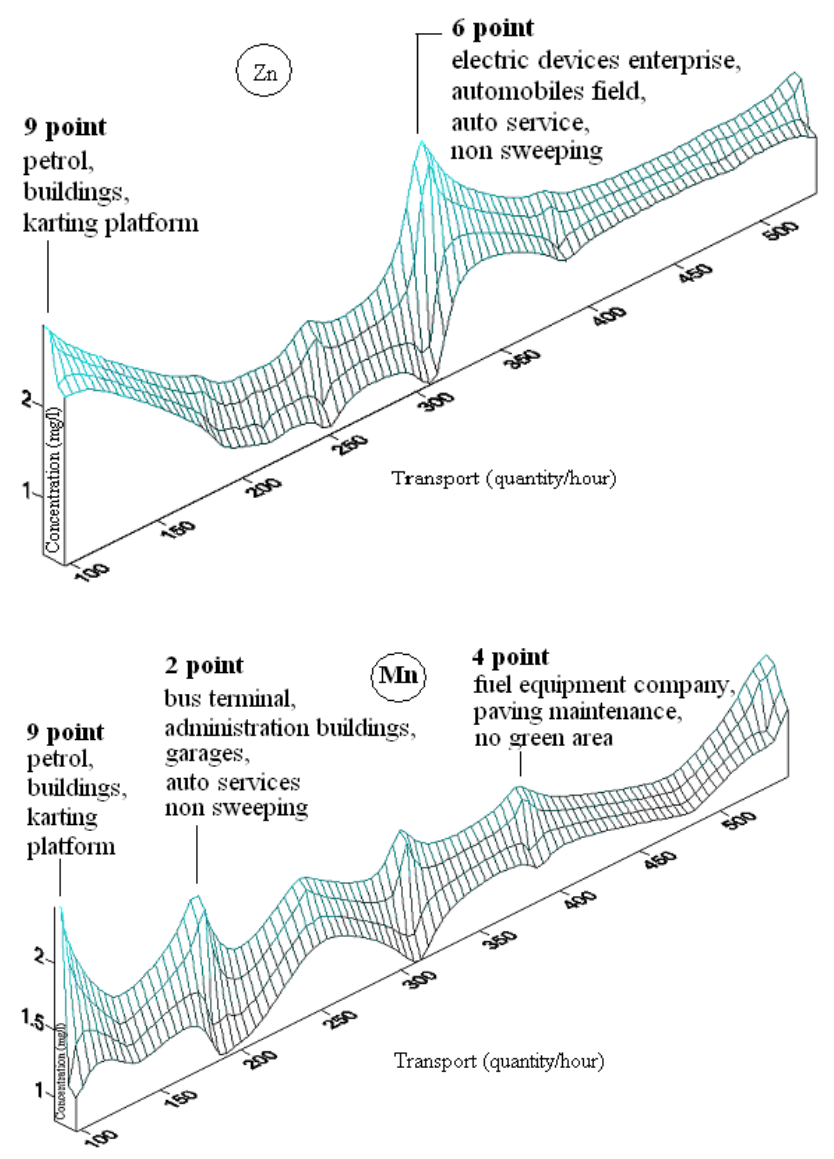

Fig. 4. Common heavy metals concentration (mg/l) of sweeps by transport intensity

Generalized concentrations of heavy metals in street sweeps from different points and in sludge from outflow pipes are given in Table 2. Every analyzed point with samples taken belongs to different sewage collection pool, where the water is released to the river. A more detailed information on transport quantity flows and sampling points for eacht pool is also given in Table 2.

The highest concentration of heavy metals is found in outflow pipes 1, 4 and 7. Outflow pipes 1 and 7 are installed near bridges. The named three pipes belong to the pools with intensive transport.

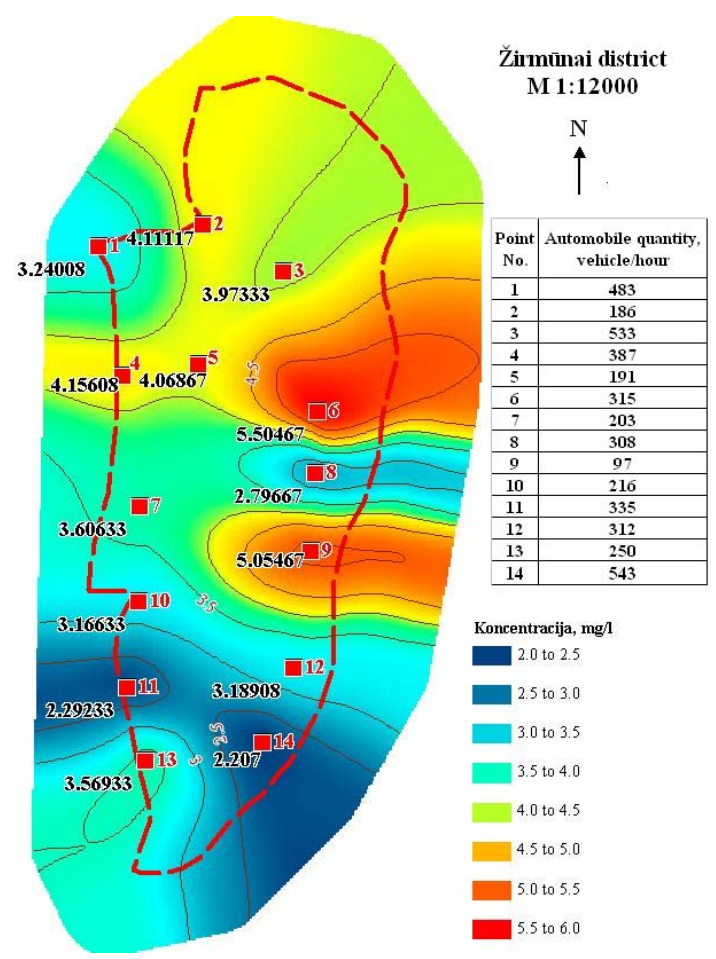

Fig. 5. Geographical spread of common pollution of heavy metals in sweeps around sampling points in Žirmūnai district

\section{A model for the spread of pollutants in the river}

Phoenics 3.5 program (acronym: Parabolic Hyperbolic Or Elliptic Numerical Integration Code Series), belonging to CHAM (Concentration Heat and Momentum Limited) is applied to constitute a model for determening the heavy metals concentration in the Neris river stream. This is a powerful Computational Fluid Dynamics (CFD) software presenting qualitative info on:

- How the fluids flow (air, water, steam, oil, blood, etc.) in equipment and around, for example in:

o engines,

o buildings,

o human body,

o rivers, lakes, oceans, etc.;

- how the composition of chemical and physical medium changes;

- how the forces influence the submerged bodies. 
Table 2. Heavy metals concentration in outflow and pollution in each watershed

\begin{tabular}{|c|c|c|c|c|c|c|c|c|c|c|c|c|c|c|c|c|c|c|}
\hline \multirow[t]{2}{*}{$\begin{array}{l}\text { Outflow } \\
\text { No. }\end{array}$} & \multicolumn{6}{|c|}{$\begin{array}{c}\text { Pollution evaluation by } \\
\text { sumarized heavy metals from } \\
\text { outflow (mg/l) }\end{array}$} & \multirow{2}{*}{\multicolumn{2}{|c|}{$\begin{array}{c}\text { Points No. of } \\
\text { sweep analyses } \\
\text { which belongs to } \\
\text { watershed }\end{array}$}} & \multicolumn{6}{|c|}{$\begin{array}{l}\text { Pollutution evaluation by } \\
\text { sumarized heavy metals in } \\
\text { sweeps (mg/l) }\end{array}$} & \multirow{2}{*}{\multicolumn{3}{|c|}{$\begin{array}{l}\text { Automobiles quantity in } \\
\text { street points (unit/hour) }\end{array}$}} & \multirow{3}{*}{\begin{tabular}{|c|}
$\begin{array}{c}\text { Sumarized } \\
\text { automobiles } \\
\text { quantity in peak } \\
\text { points of each } \\
\text { watershed }\end{array}$ \\
719 \\
\end{tabular}} \\
\hline & \multirow{2}{*}{\begin{tabular}{|l|}
$\mathbf{C r}$ \\
0,2 \\
\end{tabular}} & \multirow{2}{*}{\begin{tabular}{l|}
$\mathbf{Z n}$ \\
1,5
\end{tabular}} & \multirow{2}{*}{\begin{tabular}{c|}
$\mathbf{M n}$ \\
4,4
\end{tabular}} & \multirow{2}{*}{\begin{tabular}{|l|}
$\mathbf{N i}$ \\
0,3
\end{tabular}} & \multirow{2}{*}{$\begin{array}{l}\mathbf{P b} \\
0,4\end{array}$} & \multirow{2}{*}{\begin{tabular}{|l|}
$\mathbf{C u}$ \\
0,1
\end{tabular}} & & & \multirow{2}{*}{$\begin{array}{l}\mathbf{C r} \\
0,6\end{array}$} & \multirow{2}{*}{\begin{tabular}{|l|}
$\mathbf{Z n}$ \\
2,5
\end{tabular}} & \multirow{2}{*}{\begin{tabular}{c|} 
Mn \\
2,9
\end{tabular}} & \multirow{2}{*}{\begin{tabular}{r|}
$\mathbf{N i}$ \\
0,4
\end{tabular}} & \multirow{2}{*}{\begin{tabular}{l|}
$\mathbf{P b}$ \\
0,5
\end{tabular}} & \multirow{2}{*}{\begin{tabular}{|c|}
$\mathbf{C u}$ \\
1,4
\end{tabular}} & & & & \\
\hline 1 & & & & & & & 2 & 3 & & & & & & & 18 & & 533 & \\
\hline 3 & & 0,4 & & & & 0,2 & 1 & 5 & 0,6 & 2,3 & 2,5 & \begin{tabular}{|l|}
0,3 \\
\end{tabular} & \begin{tabular}{|l|}
0,7 \\
\end{tabular} & 0,8 & $4 \varepsilon$ & & 191 & 674 \\
\hline 4 & 0 & 0,5 & 1,9 & \begin{tabular}{|l|l|}
0,3 \\
\end{tabular} & \begin{tabular}{|l|}
0,4 \\
\end{tabular} & \begin{tabular}{|l|}
0,2 \\
\end{tabular} & \begin{tabular}{l|l}
4 & 6
\end{tabular} & 7 & 0,8 & 6,5 & 3,8 & \begin{tabular}{|l|}
0,8 \\
\end{tabular} & 0,7 & 1,5 & 387 & & & 905 \\
\hline 5 & & 0,5 & 1,8 & \begin{tabular}{|l|}
0,2 \\
\end{tabular} & 0,3 & & 8 & 9 & 0,5 & 4,0 & 3,5 & \begin{tabular}{|l|}
0,4 \\
\end{tabular} & 0,7 & 2,0 & & 308 & 97 & 405 \\
\hline 6 & 0,2 & 0,4 & 2,2 & 0,2 & \begin{tabular}{|l|}
0,3 \\
\end{tabular} & 0,2 & 1 & & 0,2 & 0,9 & 1,3 & \begin{tabular}{|l|}
0,2 \\
\end{tabular} & \begin{tabular}{|l|}
0,1 \\
\end{tabular} & 0,4 & & & & 312 \\
\hline 7 & 0,2 & 1,1 & 1,6 & \begin{tabular}{|l|}
0,2 \\
\end{tabular} & 0,4 & \begin{tabular}{|l|}
0,3 \\
\end{tabular} & 11 & \begin{tabular}{l|l|}
13 & 14 \\
\end{tabular} & 0,7 & 12,4 & \begin{tabular}{|l|}
5,1 \\
\end{tabular} & \begin{tabular}{|c|}
0,7 \\
\end{tabular} & 3,6 & 1,9 & 216 & 135 & 250 & 1144 \\
\hline $\begin{array}{l}\text { MPC } \\
(\mathrm{mg} / \mathrm{ll})\end{array}$ & 0,5 & 0,4 & - & 0,2 & 0,1 & 0,5 & & & 0,5 & 0,4 & - & 0,2 & 0,1 & 0,5 & & & & \\
\hline
\end{tabular}

Cells in grey exceed MPC and have maximum values of transport Empty cells - results are above confidence interval

Phoenics program depends on three major functions: 1. task making (pre-processing), where the user describes situation to be solved;

2. modeling (data-processing), where the program calculates the determined conditions by the laws of science;

3. data provision (post-processing), where calculation results are provided in a graphical form (PHOENICS Overview ... 2007).

Program for modeling solves a differential equation by Navie-Stocks (1) (Baltrènas et al. 2004, 2008; Ruther et al. 2005):

$$
\operatorname{div}\left(\rho \overrightarrow{\mathbf{V}} \Phi-\Gamma_{\Phi} \operatorname{grad} \Phi\right)=S_{\Phi}
$$

where: $\rho$ - thickness $\mathrm{kg} / \mathrm{m}^{3}$; $\Phi$ - dependent variable (enthalpy, power of turbulence, etc.); $\vec{v}$ - speed vector; $\Gamma_{\Phi}-$ $\Phi$ variable diffusion coefficient (coefficient of kinematic viscosity of movement equations, difussion coefficient of diffussion equations); $S_{\Phi}-\Phi$ member of variable flow rate equation.

A model for the spread of heavy metals in the Neris river from six storm wastewater outflows is made. Computerized modeling system - a tool for determening water quality when the pollutants get to the river.

Modeling process starts at the task window (Phoenics Commander Window), where task data are entered in to Q1 file. river:

The required data for making a model for the Neris

- size of the river (domain):

$\mathrm{x}$ - width $40 \mathrm{~m}$ (Neris is $80 \mathrm{~m}$ wide, but in this case, only half of the river is analyzed in Žirmūnai district),

$\mathrm{y}-$ depth $3 \mathrm{~m}$,

$\mathrm{z}$ - length $4000 \mathrm{~m}$ in Žirmūnai district, while a segment taken for this model is $200 \mathrm{~m}$;

- water pressure $\mathrm{P}=1.0 \cdot 10^{5} \mathrm{~Pa}$;

- water density $\rho=9.98 \cdot 10^{2} \mathrm{~kg} / \mathrm{m}^{3}$;

- river speed $\mathrm{V}=1 \mathrm{~m} / \mathrm{s}$;

- water speed from the outflow pipes $\mathrm{W}=2 \mathrm{~m} / \mathrm{s}$;

- concentration C $\left(\mathrm{mg} / \mathrm{m}^{3}\right)$ of heavy metals $(\mathrm{Pb}, \mathrm{Mn}$, $\mathrm{Cr}, \mathrm{Zn}, \mathrm{Cu}, \mathrm{Ni})$.

After filling the Q1 file and before the program makes calculations, information should be read with Phoe- nics Satellite. Information is transferred in this way to the Satellite. Before providing a graphical representation of results, equations are solved with the help of Solver (Jankaite 2009; Paliulis 2006; Phoenics...2008).

For making the model, friction power, when the speed of water in the river $\mathrm{V}$ is close to zero beside the shore line and on the water ground, is considered. In this model, the total concentration of heavy metals from each outflow pipe and spread of pollutants analysed by the direction of river flow is taken.

Fig. 6 shows heavy metal spread in the river from the outflow pipe 1 (outflow 1) with the highest concentration. The background of concentration is seen until the $30 \mathrm{~m}$ distance. At a $23 \mathrm{~m}$ distance the concentration reaches around $2 \mathrm{~m}$ depth, but it is around 8 times smaller. The highest concentration spreads up to $6-7 \mathrm{~m}$ of the river length and $0.4 \mathrm{~m}$ depth.

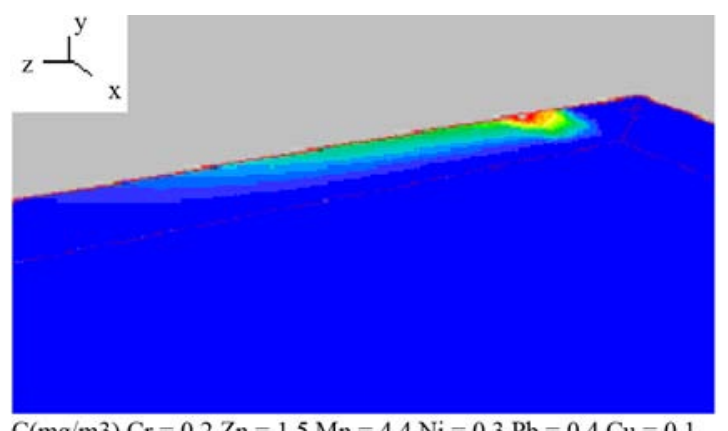

$\mathrm{C}(\mathrm{mg} / \mathrm{m} 3) \mathrm{Cr}=0.2 \mathrm{Zn}=1.5 \mathrm{Mn}=4.4 \mathrm{Ni}=0.3 \mathrm{~Pb}=0.4 \mathrm{Cu}=0.1$ a - outflow 1

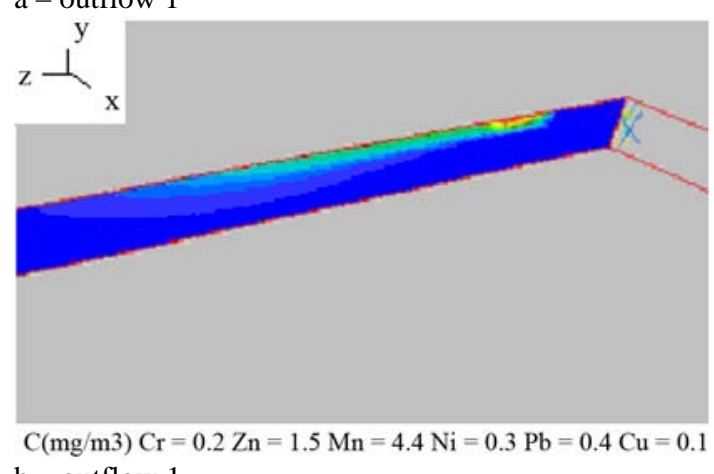

b - outflow 1

Fig. 6. Heavy metals spread from outflow with maximum concentration: $\mathrm{a}$ - river surface, $\mathrm{b}$ - river depth 
From the outflow pipe 3 (outflow 3) spread of pollutants is hardly visible, because concentration of heavy metals here is the smallest. At this point, concentration of pollutants stops spreading after $4-5 \mathrm{~m}$ length to the direction of river flow and spreads up to the depth of $0.3 \mathrm{~m}$ (Fig. 7).

Spread of pollutants from all the outflow pipes is shown in Fig. 8. Spread of pollutants grows together with the river flow and in this way pollutants spread in the river depth and width, therefore the named model shows a smaller background of concentration from the first outflow pipes. Pollutants move downstream because of advection and concentration decreases because of their spread and mixing with water. From the third outflow pipe concentration reaches river ground where the heavy metals accumulate in the sludge, living organisms and do not disappear from the natural cycle.

Distance of the spread of pollutants depends on the turbulance, water vortex, speed. The Neris river debit is $116 \mathrm{~m}^{3} / \mathrm{s}$, pollutants are flown about $600 \mathrm{~m}$ in a day, it means about $25 \mathrm{~m}$ an hour (Pollution of ... 2008).

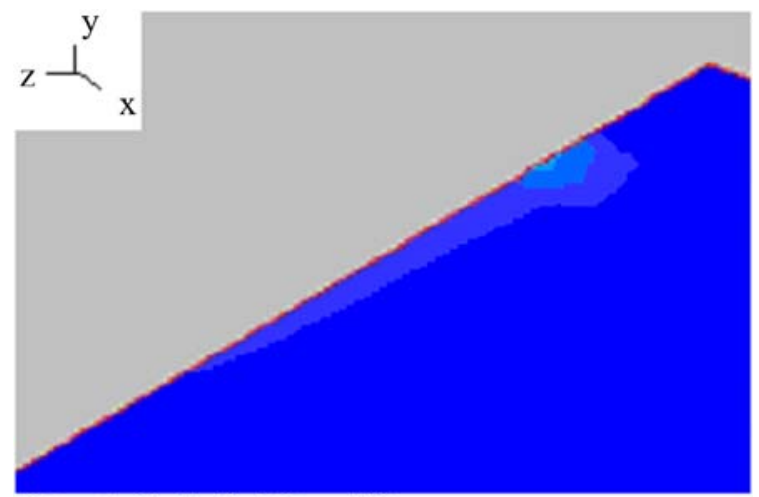

$\mathrm{C}(\mathrm{mg} / \mathrm{m} 3) \mathrm{Zn} 0.4 \mathrm{Cu}=0.2$

other metals results are under confindence interval a - outflow 3

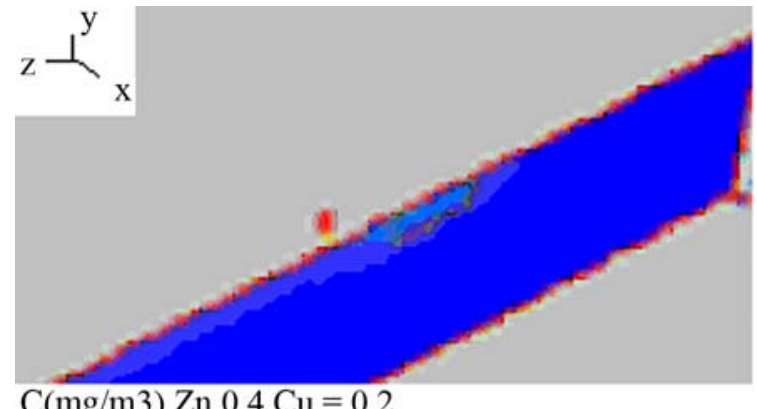

other metals results are under confindence interval b - outflow 3

Fig. 7. Heavy metals spread from outflow with minimum concentration: $\mathrm{a}$ - river surface, $\mathrm{b}$ - river depth a)

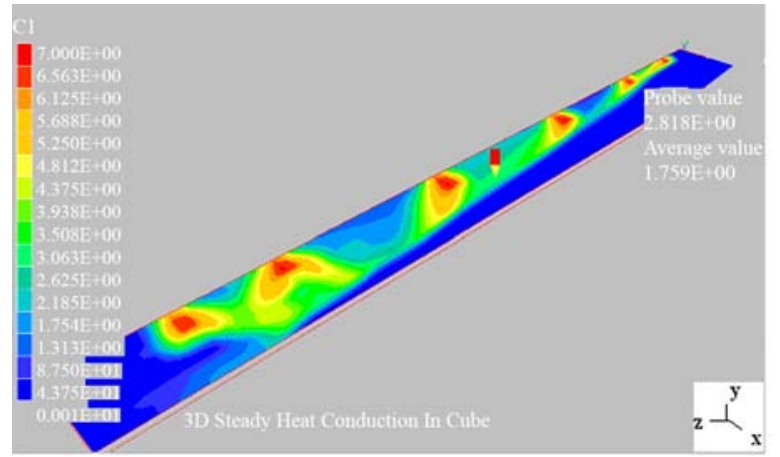

b)

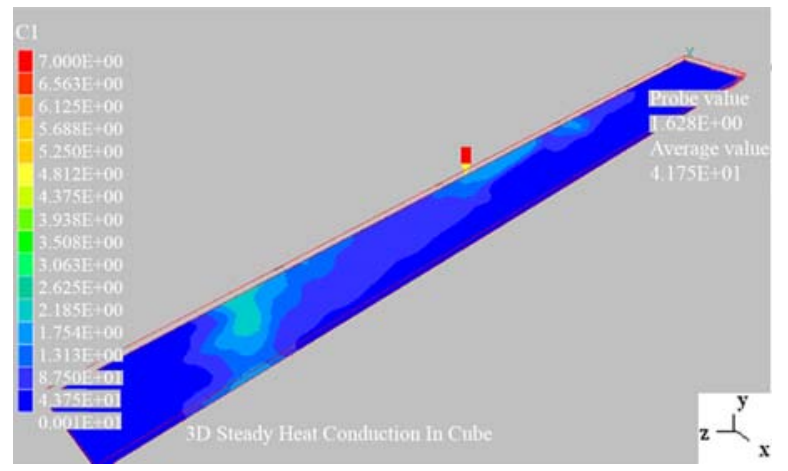

Fig. 8. Heavy metals spread from outflow in river model: $\mathrm{a}$ - river surface; $\mathrm{b}$ - river floor

\section{Conclusions}

1. According to the experimental model data, by performing a flame atomic absorption spectrometry method, heavy metal concentration in street sweep, as determined from the sweep out of intensive transportation points in Žirmūnai district, directly depends on transport amounts. Heavy metals concentration in street sweep from the streets is influenced by the nearby residing companies, oil stations, car repair shops, other buildings, frequency of car stops and their speed, street cleaning frequency, greenery.

2. Heavy metals concentration from the storm wastewater outflow pipes depends on the pollution level and car quantity in that pool, which itself falls into another pool.

3. The highest concentrations measured are $\mathrm{Mn}, \mathrm{Zn}, \mathrm{Cu}$ (in street sweep) and $\mathrm{Pb}$ (in sludge). According to the Hygienic standards HN 60:2004 (Highest permissible concentrations of hazardous chemical substances in the soil) heavy metals in street sweep and sludge exceed the permissible levels 1.1-11 times.

4. Average concentration of every heavy metal $\mathrm{Pb}, \mathrm{Mn}, \mathrm{Cr}$, $\mathrm{Zn}, \mathrm{Cu}, \mathrm{Ni}$ in street sweeps is $2-3$ times higher than in sludge from the outflow pipes.

5. The analysed heavy metals $\mathrm{Pb}, \mathrm{Mn}, \mathrm{Cr}, \mathrm{Zn}, \mathrm{Cu}, \mathrm{Ni}$ from storm wastewater outflow pipes without any cleaning fall directly to the river and flow by the direction of the river. Concentration of pollutants, as the model shows, decreases because of turbulance. 


\section{References}

Baltrėnas, P.; Morkūnienė, J.; Vaitiekūnas, P. 2008. Mathematical simulation of solid particle dispersion in the air of Vilnius city, Journal of Environmental Engineering and Landscape Management 16(1): 15-22. doi:10.3846/1648-6897.2008.16.15-22

Baltrènas, P.; Vaitiekūnas, P.; Katinas, V.; Markevičius, A. 2004. Two-phase modelling of thermal dissipation in a natural basin, Journal of Environmental Engineering and Landscape Management 8(3): 27-31.

Brannvall, E.; Martinėnas, B. 2007. Smulkiujų dalelių sklaidos i šalikelę ypatybės [Characteristics of particles spread to roadside], The Baltic Journal of Road and Bridge Engineering 2(1): 39-44.

Csereklye, E. K. 2010. Monitoring of landscape combinations and concourses in the Hungarian Danube-bend, Journal of Environmental Engineering and Landscape Management 18(1): 5-12. doi:10.3846/jeelm.2010.01

Davis, A.; Shokouhian, M.; Ni, S. 2001. Loading estimates of lead, copper, cadmium, and zinc in urban runoff from specific sources, Chemosphere 44(5): 997-1009.

German, J.; Svensson, G. 2002. Metal content and particle size distribution of street sediments and street sweeping waste, Water Science and Technology 46(6-7): 191-198.

Jankaite, A. 2009. Soil remediation from heavy metals using mathematical modelling, Journal of Environmental Engineering and Landscape Management 17(2): 121-129. doi:10.3846/1648-6897.2009.17.121-129

Jankauskaitė, M. 2002. Urbanizuotos aplinkos gamtinio savivalos potencialo vertinimo metodologiniai aspektai [Methodology of urbanized environment recovery assessment], Geografijos metraštis [Geography annual] 35: 274-291.
Jucevičienè, N. 2003. Kritulių užterštumo tyrimai Kauno mieste [Research of polluted precipitation in Kaunas city], Aplinkos tyrimai, inžinerija ir vadyba [Environmental research, engineering and management] 2(24): 44-47.

Lee F.; Jones-Lee, A. 2006. Lead as a stormwater runoff pollutant, Stormwater 7(6): 12-15.

Matuzevičius, A.; Rimeika, M. 1999. Lietaus stebejjimų Kaune duomenu apdorojimas [Datas processing of precipitations supervision in Kaunas], Aplinkos inžinerija [Environmental Engineering] 11(2): 54-61.

Paliulis, D. 2006. Numerical Modeling of kinetics of heavy metal sorption from polluted water, Journal of Environmental Engineering and Landscape Management 14(1): $10-15$.

PHOENICS Overview [online]. 2008. [Cited 4 March 2008]. Available from Internet: <http://www.simuserve.com/ phoenics/d_polis/d_docs/tr001/tr001.htm.>.

Pollution of the River and Reefs [online]. 2008. [Cited 20 April 2008]. Available from Internet:

<http://www.waitangi-tribunal.govt.nz/reports/ viewchapter.asp $>$.

Ruther, N.; Singh, J. M.; Olsen, N. R. B.; Atkinson, E. 2005. 3-D computation of sediment transport at water intakes, Water Management 158(158): 1-8. doi:10.1680/wama.2005.158.1.1

Sörme, L.; Lagerkvist, R. 2002. Sources of heavy metals in urban wastewater in Stockholm, The Science of the Total Environment 298(1-3): 131-145. doi:10.1016/S0048-9697(02)00197-3

Taraškevičius, R.; Radzevičius, A. 1998. Sunkiujų metalų žemèlapiai - miestu savivaldybèse [Heavy metals maps in city municipalities], Mokslas ir gyvenimas [Science and life] 9: 10-21.

\section{SUNKIUৃJŲ METALŲ KIEKIŲ TYRIMAS LIETAUS NUOTEKŲ IŠLEISTUVUOSE NUO VILNIAUS ŽIRMŪNŲ RAJONO IR JŲ SKLAIDOS MODELIS UPĖJE}

\section{S. Vasarevičius, A. Mineikaitė, P. Vaitiekūnas}

\section{Santrauka}

Nagrinejjama nevalomų lietaus nuotekų tarša sunkiaisiais metalais Vilniaus Žirmūnų rajone. Siekiant nustatyti ryši tarp lietaus nuotekų užterštumo sunkiaisiais metalais nuo transporto eksperimentiškai tiriamos sąšlavos nuo gatvių, kuriuos su lietumi išplaunamos į upę. Taip pat tiriami sunkieji metalai iš lietaus ištekamujų vamzdžių i Nerị. Eksperimentiškai nagrinėjami šie sunkieji metalai: $\mathrm{Pb}, \mathrm{Mn}, \mathrm{Cr}, \mathrm{Zn}, \mathrm{Cu}$, Ni. Tam panaudotas liepsnos absorbcijos spektrometrinis metodas. Trumpai aptariamas analizės procesas ir pateikiami tyrimų rezultatai. Remiantis gautais rezultatais sudaromas matematinis teršalų sklaidos modelis Neries upès tėkmèje taikant Phoenics 3.5 programa.

Reikšminiai žodžiai: lietaus nuotekos, išleistuvai, sunkieji metalai, gatvių sąšlavos, Neries upè, Žirmūnai, teršalų sklaida.

\section{ИССЛЕДОВАНИЕ КОЛИЧЕСТВА ТЯЖЕЛЫХ МЕТАЛЛОВ В ДОЖДЕВЫХ СТОКАХ РАЙОНА ЖИРМУНАЙ ГОРОДА ВИЛЬНЮСА И МОДЕЛЬ ИХ РАСПРЕДЕЛЕНИЯ В РЕКЕ}

\section{С. Васарявичюс, А. Минейкайте, П. Вайтекунас}

Резюме

Исследуется загрязнение неочищаемых дождевых стоков тяжелыми металлами в районе Жирмунай г. Вильнюса. Для определения степени загрязнения дождевых стоков тяжелыми металлами от транспорта экспериментально исследовался мусор с улиц, вымываемый с дождем в реку. Также исследовались тяжелые металлы в дождевых стоках, попадающих в реку Нерис. Экспериментально с применением абсорбционно-спектрометрического метода исследовались тяжелые металлы $\mathrm{Pb}, \mathrm{Mn}, \mathrm{Cr}$, $\mathrm{Zn}, \mathrm{Cu}, \mathrm{Ni}$. Рассмотрен процесс анализа и результаты исследований. На основе полученных результатов составлена математическая модель распределения загрязняющих веществ в течении реки.

Ключевые слова: дождевые стоки, тяжелые металлы, очистка, река, Жирмунай, распределение загрязняющих веществ. 
Saulius VASAREVIČIUS. Dr Assoc. Prof. (since 1999), senior research worker, Institute of Environmental Protection, Vilnius Gediminas Technical University (VGTU). Doctor of Science (environmental engineering), VTU (now VGTU), 1995. Master of Science, VTU, 1991. First degree in Civil Engineering and Management, Vilnius Civil Engineering Institute (VISI, now VGTU), 1989. Publications: author of more than 30 research papers and monographs. Probation in Germany. Research interests: environmental management, air pollution, waste management.

Asta MINEIKAITE். Master (Environmental Management and Cleaner Production Program), Dept of Environmental Engineering, Vilnius Gediminas Technical University (VGTU). Bachelor of Science (Environmental Engineering), VGTU, 2006. Research interests: water pollution, environmental management.

Petras VAITIEKŪNAS. Dr Habil. Prof. of Dept of Environmental Protection, Vilnius Gediminas Technical University (VGTU). Doctor Habil of Science (energy and thermal engineering) Lithuanian Energy Institute, 1999. Doctor of Science Laboratory of Fluid Dynamics in Heat Exchangers Lithuanian Energy Institute, 1972. Employment: Professor (2002), Associate Professor (1997). Publications: author of 1 monograph, 2 educational books, over 230 research papers. Work on probation: Prof D. Brian Spalding, Concentration, Heat and Momentum Limited, Bakery House, 40 High Street, Wimbledon Village, London SW19 5AU, UK (PHOENICS 1.4 EP CFD), January- February 1996, and (PHOENICS 3.1 VR CFD), April-May 1998. Membership: prize-winner of the Republic of Lithuania (2006), a corresponding Member of International Academy of Ecology and Life Protection.

Research interests: hidrodynamics, convective heat and mass transfer and thermophysics, computational fluid dynamics, mathematical modeling of transfer processes in the environment. 